\title{
Peran Dukungan Keluarga dan Konsep Diri Terhadap Peningkatan Keterampilan Sosial Anak Tunarungu Di Sekolah Inklusif
}

\author{
Lana PratiwiRukmana. S1, Wiwin Hendriani ${ }^{2}$ \\ 1,2Fakultas Psikologi Universitas Airlangga \\ e-mail: *11anapratiwi@gmail.com, 2wiwin.hendriani@psikologi.unair.ac.id
}

\begin{abstract}
This research aims to find out whether there is an influence of family support and self-concept on social skills of deaf children in inclusive schools. The data collection tool of this study uses a questionnaire with a family support scale compiled by the author based on the theory of Caplan (1976), the scale of self-concept compiled by the author based on the theory of Caldarella \& Merrel (2003). The reliability of the family support scale is 0.913 self-concept scale of 0.969 and the social skill scale is 0.892 . Data analysis in this study was carried out by multiple regression techniques. Based on the results of the data analysis, the influence of family support and self-concept on social skills in Deaf children with a significance value of $0,000, R$ value of 0.983 and $R$ square of 0.966 indicates that the contribution percentage of the variable family support and self-concept is $96.6 \%$ while the remaining $3.4 \%$ is influenced or explained by other variables that are not used.
\end{abstract}

Keywords: social skills; family support; self concept.

Abstrak. Penelitian ini di bertujuan untuk mengetahui apakah terdapat pengaruh dukungan keluarga dan konsep diri pada keterampilan social anak tunarungu di sekolah inklusif. Alat pengumpul data penelitian ini menggunakan kuisioner dengan skala dukungan keluarga yang disusun penulis berdasarkan teori Caplan (1976), skala konsep diri yang disusun penulis berdasarkan teori Caldarella \& Merrel (2003). Reliabilitas skala dukungan keluarga sebesar 0,913 skala konsep diri sebesar 0,969 dan skala keterampilan sosial sebesar 0,892. Analisis data pada penelitian ini dilakukan dengan teknik regresi berganda. Beerdasarkan hasil analisis data diperoleh pengaruh dukungan keluarga dan konsep diri terhadap keterampilan sosial pada anak Tunarungu dengan nilai signifikansi sebesar 0,000 , nilai $R$ sebesar 0,983 dan $R$ square sebesar 0,966 hal ini menunjukkan bahwa presentase sumbangan pengaruh variable dukungan keluarga dan konsep diri sebesar 96,6 \% sedangkan sisanya 3,4 \% dipengaruhi atau dijelaskan oleh variable lain yang tidak digunakan.

Kata Kunci : keterampilan sosial ; dukungan keluarga ; konsep diri. 
Philanthrophy Journal of Psychology

Vol 2 Nomor 1 (2018), 37-54

ISSN 2580-6076 (Print), ISSN 2580-8532 (Online)

\section{Pendahuluan}

Pendidikan inklusif dapat dipandang sebagai pergerakan yang menjunjung tinggi nilai-nilai, keyakinan, dan prinsip-prinsip utama yang berkaitan dengan anak, pendidikan, keberagaman, dan diskriminasi, proses partisipasi dan sumber-sumber yang tersedia (Stubbs, 2002). Sekolah inklusif memiliki keunggulan dibandingkan dengan pendidikan khusus, salah satunya untuk menfasilitasi agar murid anak berkebutuhan khusus dengan reguler dapat saling berinteraksi, sehingga akan memberi dampak yang baik ke perkembangan ketrampilan sosial siswa $\mathrm{ABK}$, termasuk di dalamnya siswa Tunarungu. Siswa tunarungu adalah siswa yang mengalami kekurangan atau kehilangan kemampuan mendengar baik sebagian maupun seluruhnya yang diakibatkan oleh ketidakberfungsiannya sebagian atau seluruh alat pendengaran, sehingga ia tidak dapat menggunakan alat pendengarannya dalam kehidupan sehari-hari, yang berdampak terhadap kehidupannya secara kompleks terutama pada kemampuan bahasa sebagai alat komunikasi yang sangat penting (Winarsih, 2007).

Akan tetapi pada kenyataannya dampak baik pendidikan inklusif tidak selalu tampak pada siswa, dalam hal ini siswa Tunarungu. Masih ada siswa-siswa tunarungu di sekolah inklusi yang memiliki persoalan keterampilan sosial. Sebagai contoh penelitian yang dilakukan oleh Rini, (2014), yang menemukan bahwa keterampilan social yang dimiliki anak tunarungu masih rendah. Hal ini ditandai oleh kurangnya kepekaan anak tunarungu terhadap rangsangan sosial dalam berinteraksi di lingkungan sosialnya. Penelitian lain yang dilakukan oleh Tanjung (2014) juga menemukan bahwa anak tunarungu, yaitu Ay dan As yang menjadi subjek juga masih belum dapat menunjukkan keterampilan bersosialisasi dengan lingkungannya. Menurut guru kelas, Ay memang masih cenderung emosional, manja, dan pemalu. Berdasarkan temuan penelitian terdahulu tentang adanya persoalan keterampilan sosial pada siswa tunarungu tersebut menjadi dasar peneliti mengkaji lebih jauh, untuk mencari tahu apa yang menyebabkannya. Keterampilan sosial siswa berdasarkan penelitian terdahulu dipengaruhi oleh sejumlah faktor. Pertama, keterampilan sosial dipengaruhi oleh dukungan keluarga. Hal tersebut dapat dilihat dari penelitian yang dilakukan oleh Mulyana dan Matiudin (2018). Keterampilan sosial yang kurang pada anak tunarungu dapat diminimalisir oleh keluarga karena keluarga adalah orang yang paling dekat dan mempunyai intensitas baik untuk bersama dengan anak tunarungu. Pada penelitian Alfi (2005), menyatakan tidak semua remaja tunarungu mengalami pandangan negatif, beberapa dari mereka ada yang berhasil mengatasi permasalahan sosial dikarenakan adanya konsep diri yang positif mengenai dirinya sehingga menampilkan kesan yang baik 
Philanthrophy Journal of Psychology

Vol 2 Nomor 1 (2018), 37-54

ISSN 2580-6076 (Print), ISSN 2580-8532 (Online)

jika berhubungan dengan orang di sekitarnya. Penelitian ini membuktikan keterkaitan antara dukungan keluarga dan konsep diri terhadap ketrampilan sosial.

\section{Metode}

Adapun penjabaran variabel yang akan diteliti dalam penelitian ini adalah sebagai berikut : variabel terikat (Y) : keterampilan sosial, variabel bebas (X1) : dukungan keluarga dan variabel bebas (X2) : konsep diri.

\section{Subjek}

Berkenaan dengan penelitian ini maka akan dijadikan populasi dalam penelitian ini adalah siswa tuna rungu sekolah inklusif berjumlah 30 siswa yang memenuhi beberapa karakteristik yang mendukung, yaitu :

a. Anak tuna rungu (taraf ringan) yang bersekolah di sekolah inklusif.

b. Anak tuna rungu tersebut adalah siswa yang memasuki tahun kedua atau lebih di sekolah inklusif, karena pada tahun kedua siswa tuna rungu sudah mendapatkan proses adaptasi yang cukup.

c. Kelas VIII : 11 dan kelas IX : 19

Penelitian ini menggunakan tiga instrumen penelitian yang akan mengukur tingkat keterampilan sosial, dukungan keluarga dan konsep diri. Instrumen penelitian ini untuk mengukur tingkat keterampilan sosial (KS) pada anak tuna rungu akan diukur menggunakan skala yang disususn oleh peneliti berdasarkan aspek-aspek keterampilan sosialterdapat 40 aitem berbentuk skala likert yang digunakan untuk mengukur keterampilan sosial anak tunarungu.instrumen untuk mengukur dukungan keluarga menggunakan skala dukungan keluarga yang disusun oleh peneliti berdasarkan instrumen ini. Terdiri dari 30 aitem. Instrumen untuk mengukur konsep diri menggunakan skalakonsep diri dengan tipe likert yang disusun oleh peneliti. Skala tersebut berisi 48 pernyataan berdasarkan dimensi Konsep diri.

Teknik analisis yang akan digunakan dalam penelitian ini adalah teknik analisis regresi linier berganda dengan bantuan IBM SPSS 24.0 for windows. Tenik analisis ini digunakan sesuai dengan tujuan peneliti yaitu untuk mengetahui apakah terdapat pengaruh dukungan keluarga dan strategi konsep diri terhadap keterampilan sosial pada anak tunarungu di sekolah inklusif Surabaya. 


\section{Diskusi}

\section{Analisis Deskriptif}

Statistik deskriptif lebih berhubungan dengan pengumpulan dan peringkasan data, serta penyajian hasil peringkasan tersebut. Data tersebut harus diringkas dengan baik dan teratur sebagai dasar untuk pengambilan keputusan. Data deskriptif terdiri dari mean variabel terikat pada setiap variasi tingkatan variabel bebas, standar deviasi, dan jumlah subjek pada setiap variasi tingkatan masing-masing variabel bebas. Analisis data deskriptif ini menggunakan bantuan program SPSS 24.0 for windows. Analisis deskriptif berfungsi untuk mendeskripsikan objek yang diteliti melalui data sampel sebagaimana adanya, tanpa melakukan analisis dan membuat kesimpulan berlaku umum.

Tabel 4.2

Analisis Deskriptif

\begin{tabular}{lcccccc}
\hline \multicolumn{7}{c}{ Descriptive Statistics } \\
& & Minimu & Maximu & & \\
& $\mathrm{N}$ & $\mathrm{m}$ & $\mathrm{m}$ & Sum & Mean & $\begin{array}{c}\text { Std. } \\
\text { Deviation }\end{array}$ \\
\hline $\begin{array}{l}\text { Dukungan } \\
\text { Keluarga }\end{array}$ & 30 & 71 & 136 & 3171 & 105,70 & 18,100 \\
\hline Konsep diri & 30 & 77 & 171 & 3488 & 116,27 & 29,486 \\
\hline Keterampil & 30 & 54 & 102 & 2416 & 80,53 & 13,816 \\
an Sosial & & & & & & \\
\hline Valid N & 30 & & & & & \\
(listwise) & & & & & & \\
\hline
\end{tabular}

Dari tabel 4.2 dapat disimpulkan bahwa seluruh data valid atau sah untuk diolah tannpa adanya missing atau data yang hilang. Hal ini berlaku untuk semua data baik data keterampilan sosial, dukungan keluarga, maupun konsep diri. Mean adalah jumlah seluruh angka pada data dibagi dengan jumlah data yang ada (Azwar, 2013.) adapun nilai mean untuk keterampilan sosial adalah 80,53 dukungan keluarga 105,70 dan konsep diri 116,27 analisis berikutnya adalah SD atau Standard Deviation yang merupakan suatu ukuran penyimpangan. Jika nilainya kecil maka data yang digunakan mengelompok disekitar nilai rata-rata (Azwar, 2013) 


\section{Hasil Uji Normalitas}

Tabel 4.3

Hasil Uji Normalitas

One-Sample Kolmogorov-Smirnov Test

\begin{tabular}{lllll}
\hline & & $\begin{array}{l}\text { Dukungan } \\
\text { Keluarga }\end{array}$ & $\begin{array}{l}\text { Konsep } \\
\text { diri }\end{array}$ & $\begin{array}{l}\text { Keterampil } \\
\text { an Sosial }\end{array}$ \\
\hline $\mathrm{N}$ & & 30 & 30 & 30 \\
\hline Normal & Mean & 105.7000 & 116.2667 & 80.5333 \\
Parametersa,b & Std. & 18.09963 & 29.48633 & 13.81587 \\
\cline { 2 - 5 } & Deviation & & & \\
\hline Most Extreme & Absolute & .086 & .131 & .102 \\
Differences & Positive & .074 & .131 & .078 \\
\cline { 2 - 5 } & & & & \\
\cline { 2 - 5 } & Negative & -.086 & -.094 & -.102 \\
\cline { 2 - 5 } & & & & \\
\cline { 2 - 5 } & & & & \\
\end{tabular}

\begin{tabular}{llll} 
Kolmogorov-Smirnov Z & .469 & .719 & .558 \\
\hline Asymp. Sig. (2-tailed) & .981 & .679 & .915 \\
\hline
\end{tabular}

a. Test distribution is Normal.

b. Calculated from data.

Berdasarkan hasil uji normalitas diatas, dapat dilihat bahwa variabel dependent (Y) yaitu keterampilan sosial memiliki nilai signifikasi 0,915 hal tersebut menunjukkan bahwa variabel tersebut berdistribusi normal. Sedangkan variabel $\mathrm{X}^{1}$ dan $\mathrm{X}^{2}$ memiliki nilai signifikasi 0,981 dan 0,679 hal tersebut menunjukkan semua data berdistribusi normal karena memiliki nilai signifikasi $>0.05$, sehingga model regresi layak dipakai untuk mempredisi keterampilan sosial berdasarkan variabel bebasnya.

Peneliti menggunakan uji linieritas test of linierity menggunakan teknik compare means dengan bantuan SPSS 24.0 for windows. Nilai signifikansi dikatakan linier bila $<0,05$, dan tidak linier bila signifikansi $>0,05$, nilai signifikansi linieritas dapat dilihat pada tabel berikut : 
Philanthrophy Journal of Psychology

Vol 2 Nomor 1 (2018), 37-54

ISSN 2580-6076 (Print), ISSN 2580-8532 (Online)

\section{Hasil Uji Linearitas}

Tabel 4.4

Hasil Uji Linearitas

ANOVA Table

\begin{tabular}{|c|c|c|c|c|c|c|c|}
\hline & & & Sum of & & & & \\
\hline & & & Square & & Mean & & \\
\hline & & & $\mathrm{s}$ & $\mathrm{df}$ & Square & $\mathrm{F}$ & Sig. \\
\hline Dukungan & Between & (Combined) & 9479.8 & 23 & 412.16 & 120.6 & .00 \\
\hline Keluarga * & Groups & & 00 & & 5 & 34 & 0 \\
\hline Keterampilan & & Linearity & 8996.2 & 1 & 8996.2 & 2633. & .00 \\
\hline Sosial & & & 47 & & 47 & 048 & 0 \\
\hline & & Deviation & 483.55 & 22 & 21.980 & 6.433 & .01 \\
\hline & & from & 3 & & & & 4 \\
\hline & & Linearity & & & & & \\
\hline
\end{tabular}

\begin{tabular}{lrrr} 
Within Groups & 20.500 & 6 & 3.417 \\
\hline Total & 9500.3 & 29
\end{tabular}

00

Berdasarkan nilai dari output tabel diatas, diperoleh nilai signifikansi $0,14<0,05$ yang artinya terdapat hubungan liear secara signifikan antara variabel X ke variabel Y.

Uji asumsi multikolinieritas, dimana antara variabel X (independent) tidak boleh saling berkolerasi. Hal ini dilakukan untuk menguji apakah pada model regresi ditemukan adanya kolerasi antar variable independent. Jika terjadi kolerasi maka terdapat problem multikolinieritas. Model regresi yang baik seharusnya tidak terjadi kolerasi diantara variabel independent.

\section{Hasil Uji Multikolinearitas}

Tabel 4.5

\section{Hasil Uji Asumsi Multikolinieritas}

\begin{tabular}{lccccc}
\hline Model & $\begin{array}{c}\text { Unstandardize } \\
\text { d Coefficients }\end{array}$ & $\begin{array}{c}\text { Standardized } \\
\text { Coefficients }\end{array}$ & t & Sig. & Collinearity \\
& & & & & \\
& & &
\end{tabular}




\begin{tabular}{lcccrrrrr} 
& \multicolumn{3}{c}{ Std. } & & & & Toleran \\
& B & Error & Beta & & & ce & VIF \\
\hline 1 (Constant) & -.389 & 2.975 & & & -.897 & & \\
& & & & & .131 & & & \\
\hline Dukungan & .684 & .031 & .897 & 22.0 & .000 & .764 & 1.308 \\
Keluarga & & & & 49 & & & \\
\hline Konsep diri & .074 & .019 & .157 & 3.86 & .001 & .764 & 1.308 \\
& & & & & 9 & & & \\
\hline
\end{tabular}

\section{Coefficients $^{\mathbf{a}}$}

a.Dependent Variable: Keterampilan Sosial

Nilai tolerance 43ariable $\mathrm{x} 1$ dan 43ariable $\mathrm{x} 2$ yakni $0,764>$ dari 0,1 sementara itu, nilai vif 43ariable X1 dan X2 yakni 1,308< dari 10.00. sehingga dapat disimpilkan tidak terjadi multikolininieritas antar 43ariable independent.

\section{Hasil Uji Heterokedastisitas Glejser}

Tabel 4.6

\section{Hasil uji heterokedastisitas Glejser}

Coefficients ${ }^{\mathrm{a}}$

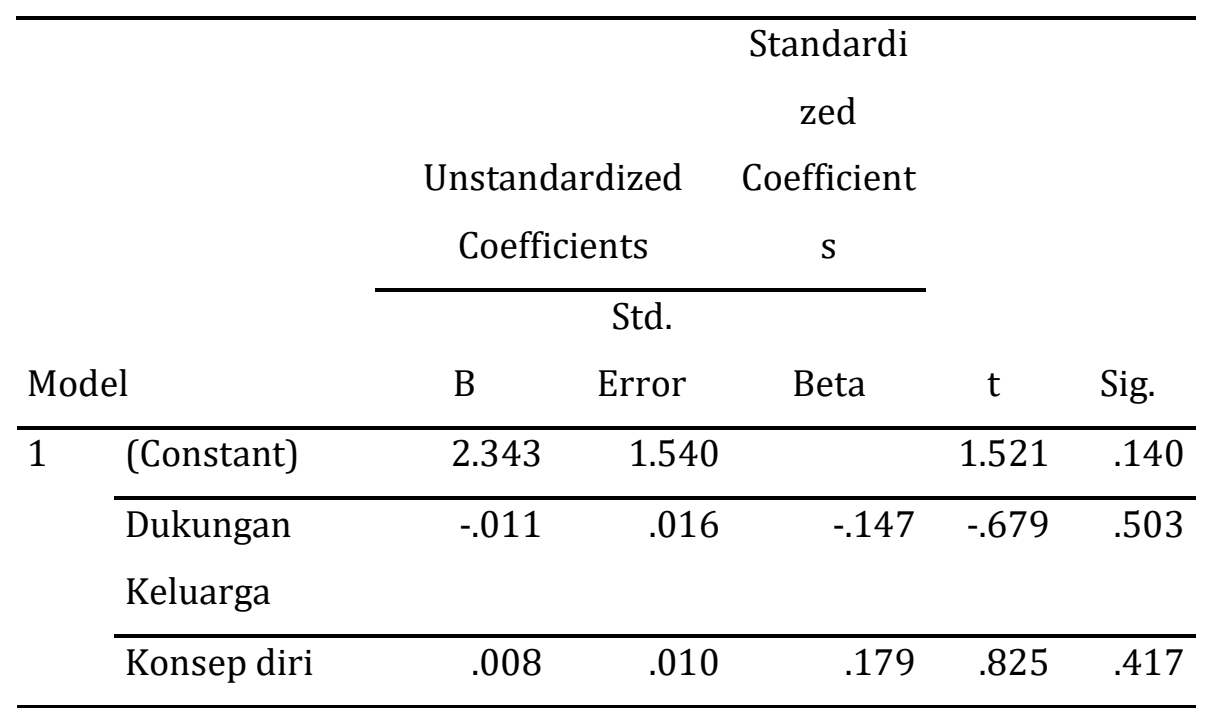

a. Dependent Variable: RES2

Pada tabel output hasil uji heterokedastisitas Glejser dapat diketahui bahwa diperoleh nilai signifikansi 0,503 pada variabel X1 dan 0,417 pada variabel X2 yang berarti > dari 0.05 . sehingga dapat disimpulkan bahwa data pada kedua variabel tidak terjadi masalah heterokedastisitas. 
Philanthrophy Journal of Psychology

Vol 2 Nomor 1 (2018), 37-54

ISSN 2580-6076 (Print), ISSN 2580-8532 (Online)

\section{Uji Autokolerasi}

Uji asumsi autokolerasi, adalah untuk melihat apakah ada kolerasi antara satu periode $\mathrm{t}$ dengan periode $\mathrm{t}-1$, secara sederhana adalah analisis regresi untuk melihat pengaruh variabel terikat dengan variabel bebas.

Tabel 4.7

Hasil Uji

\section{Asumsi Autokolerasi}

Model Summaryb

\begin{tabular}{|c|c|c|c|c|c|}
\hline Model & $\mathrm{R}$ & R Square & $\begin{array}{l}\text { Adjusted R } \\
\text { Square }\end{array}$ & $\begin{array}{l}\text { Std. Error of } \\
\text { the Estimate }\end{array}$ & Durbin-Watson \\
\hline 1 & $.983^{\mathrm{a}}$ & .966 & .963 & 2.64537 & 2.324 \\
\hline
\end{tabular}

a. Predictors: (Constant), Konsep diri, Dukungan Keluarga

b. Dependent Variable: Keterampilan Sosial

Keterangan hasil uji asumsi autokolerasi

\begin{tabular}{|cc|}
\hline$d L$ & $d U$ \\
1,2837 & 1,5666 \\
\hline
\end{tabular}

1. Jika $d W<$ dari $d L$ atau $>$ dari(4-dU), maka hipotesis nol ditolak, yang berarti terdapat autokolerasi

2. Jika dW terletak antara dU dan (4-dU), maka hipotesis nol diterima, yang berarti tidak ada autokolerasi

3. Jika d terletak anatara $\mathrm{dL}$ dan $\mathrm{dU}$ atau diantara (4-dU) dan (4-dL), maka tidak menghasilkan kesimpulan yang pasti

Hasil diatas menunjukkan bahwa $\mathrm{dW}=2,324$ sehingga hipotesis nol diterima, sehingga dapat disimpulkan bahwa data dari variabel penelitian ini tidak ada autokolerasi.

\section{Uji Koefisien Regresi secara bersama-sama (uji F)}

Uji F digunakan untuk mengetahui pengaruh variabel independen (variabel bebas) secara bersama-sama (simultan) terhadap variabel dependen (variabel terikat). Uji F dilakukan dengsn menggunakan bantuan software SPSS 20.0 for windows. 
ANOVAa $^{\mathbf{a}}$

\begin{tabular}{|c|c|c|c|c|c|c|}
\hline \multirow{2}{*}{\multicolumn{2}{|c|}{ Model }} & \multirow{2}{*}{$\begin{array}{l}\text { Sum of } \\
\text { Squares }\end{array}$} & \multirow[b]{2}{*}{$\mathrm{df}$} & \multicolumn{2}{|l|}{ Mean } & \multirow[b]{2}{*}{ Sig. } \\
\hline & & & & Square & $\mathrm{F}$ & \\
\hline \multirow[t]{4}{*}{1} & Regressio & 5346.521 & 2 & 2673.261 & 382.00 & $.000^{\mathrm{b}}$ \\
\hline & $\mathrm{n}$ & & & & 4 & \\
\hline & Residual & 188.946 & 27 & 6.998 & & \\
\hline & Total & 5535.467 & 29 & & & \\
\hline
\end{tabular}

\section{Tabel 4.8}

\section{Hasil Uji F}

Pada tabel output asil uji $\mathrm{F}$ dapat diketahui bahwa $\mathrm{F}$ hitung sebesar 382,004 > $\mathrm{f}$ tabel sebesar 3,35 Penentuan F tabel dilakukan dengan bantuan titik presentase Distribusi F untuk Probabilitas $=0.05$. Berdasarkan kriteria pengujian bahwa :

a. Ho diterima dan $\mathrm{H}_{1}$ ditolak apabila $\mathrm{F}$ hitung $<\mathrm{F}$ tabel atau nilai Sig. $>0,05$

b. Ho ditolak dan $\mathrm{H}_{1}$ diterima apabilaF hitung $>\mathrm{F}$ tabel atau nilai Sig. $<0,05$ maka dapat disimpulkan dalam pengujian ini Ho ditolak dan $\mathrm{H}_{1}$ diterima, artinya variabel dukungan keluarga $\left(\mathrm{X}_{1}\right)$ dan variabel Konsep diri $\left(\mathrm{X}_{2}\right)$ secara bersamasama berpengaruh signifikan terhadap keterampilan sosial.

\section{8. uji koefisien regresi secara parsial (uji t)}

Pengujian ini digunakan untuk mengetahui apakah dalam model regresi, variabel dependen atau variabel bebas secara parsial berpengaruh terhadap variabel independen atau variabel terikat. Uji t dilakukan dengan bantuan software SPSS 24 for windows. 
Tabel 4.9

Hasil uji t

Coefficients $^{\mathrm{a}}$

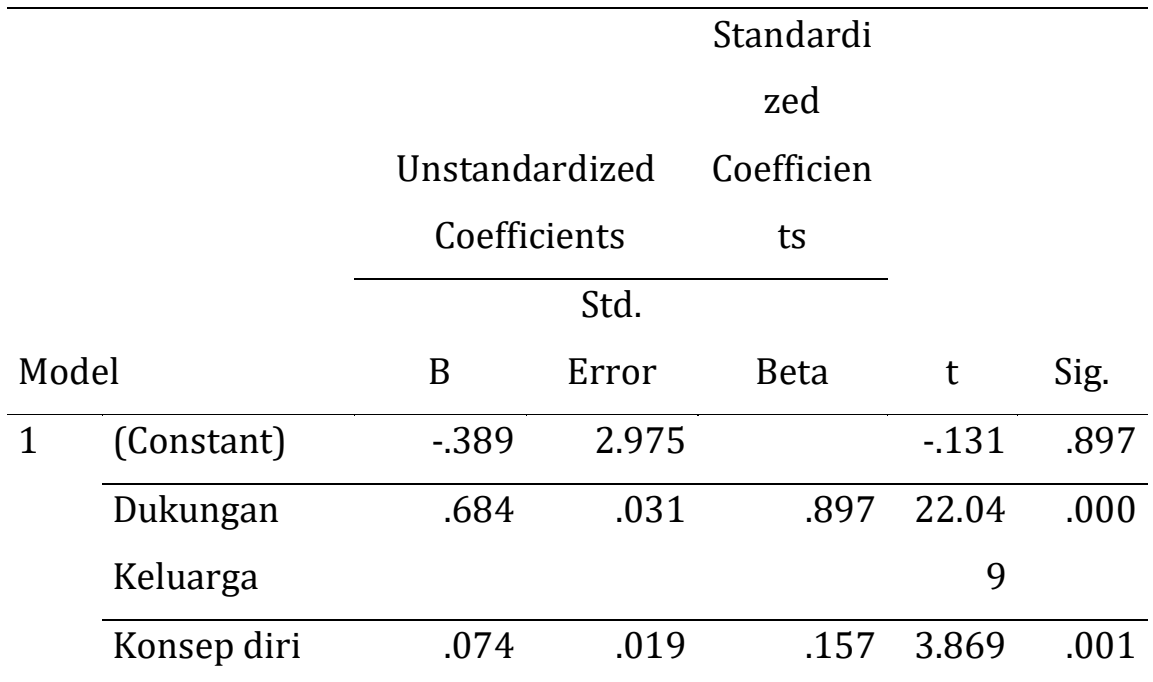

Berdasarkan output coefficients pada tabel 4.9 hasil uji t yang pertama diperoleh koefisien regresi variabel dukungan keluarga $\left(\mathrm{X}_{1}\right)$ adalah sebesar 0,897 bernilai positif. Hal ini dapat dikatakan bahwa variabel dukungan keluarga $\left(X_{1}\right)$ berpengaruh positif terhadap variabel keterampilan sosial (Y). Pengaruh positif dapat diartikan bahwa semakin meningkat dukungan keluarga, semakin meningkat pula keterampilan sosial (Y) anak tunarungu.

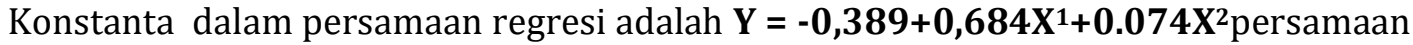
tersebut menunjukkan bahwasetiap penambahan nilai $\mathrm{X}^{1}$ (dukungan keluarga) akan meningkatkan keterampilan sosial, begitu pula untuk koefisien regresi $\mathrm{X}^{2}$ (konsep diri), setiap penambahan nilainya akan meningkaatkan variabel Y (keterampilan sosial).

Berdasarkan analisis regresi diperoleh nilai t hitung sebesar 22,049> t tabel sebesar 1,701 dan nilai signifikansi (sig.) $0.000<0.05$.penentuan t tabel dilakukan dengan bantuan tabel titik persentase distribusi t dasar pengambilan keputusan dalam uji t adalah :

a. $\mathrm{H}_{0}$ diterima dan $\mathrm{H}_{1}$ ditolak apabila nilai $\mathrm{t}$ hitung $<\mathrm{t}$ tabel atau apabila sig. $<0.05$.

b. $\mathrm{H}_{0}$ ditolak dan $\mathrm{H}_{1}$ diterima bila thitung $>\mathrm{t}$ tabel atau apabila sig. $<0.05$.

Dengan demikian dapat disimpulkan bahwa $\mathrm{H}_{0}$ ditolak dan $\mathrm{H}_{1}$ diterima, artinya secara parsial variabel dukungan sosial $\left(\mathrm{X}_{1}\right)$ berpengaruh signifikan terhadap variabel resiliensi akademik (Y). 
Philanthrophy Journal of Psychology

Vol 2 Nomor 1 (2018), 37-54

ISSN 2580-6076 (Print), ISSN 2580-8532 (Online)

Pada hasil uji t kedua variabel strategi konsep diri diperoleh t hitung sebesar 3,869> t tabel 1,701 dan nilai signifikansi 0,001 $<0.05$, berdasarkan data tersebut dapat disimpulkan bahwa $\mathrm{H}_{0}$ ditolak dan $\mathrm{H}_{1}$ diterima, artinya secara parsial variabel konsep diri berpengaruh secara signifikan terhadap variabel keterampilan sosial (Y).

\section{Uji Koefisien Determinasi $\left(R^{2}\right)$}

Uji determinasi $\left(\mathrm{R}^{2}\right)$ dalam regresi ganda digunakan untuk mengetahui besarnya (persentase) sambungan pengaruh variabel independen ( $\mathrm{X}_{1}$ dan $\mathrm{X}_{2}$ ) secara bersama-sama terhadap variabel dependen (Y). Angka koefisien dalam uji determinasi menunjukkan seberapa besar persentase variasi variabel independen yang digunakan dalam model regresi dapat menjelaskan variasi variabel dependen.

Tabel 4.9

\section{Hasil Uji Determinasi $\left(R^{2}\right)$}

Model Summary

\begin{tabular}{lcrrr}
\hline Model & R & R Square & $\begin{array}{c}\text { Adjusted R } \\
\text { Square }\end{array}$ & $\begin{array}{l}\text { Std. Error of } \\
\text { the Estimate }\end{array}$ \\
\hline 1 & $.983^{\text {a }}$ & .966 & .963 & 2.645 \\
\hline a. Predictors: (Constant), Konsep diri, Dukungan Keluarga
\end{tabular}

Berdasarkan tabel4.9 uji determinasi dapat diketahui R² (R Square) sebesar 0,966 atau 96,6 \%. Hal ini menunjukkan bahwa persentase sumbangan pengaruh variabel independen (dukungan keluarga dan konsep diri) terhadap variabel dependen (keterampilan sosial) sebesar 96,6 \% dengan kata lain, variasi variabel independen (dukungan sosial dan strategi self regulated learning) yang digunakan dalam model mampu menjelaskan sebesar 96,6\% variasi variabel dependen (resiliensi akademik), sedangkan sisanya sebesar 3,4\% dipengaruhi atau dijelaskan oleh variabel lain yang tidak dimasukkan dalam model penelitian ini.

intepretasi kekuatan hubungan antara variabel independen $(\mathrm{X})$ dengan variabel dependen $(\mathrm{Y})$ yang dinamakan koefisiensi kolerasi sebagai berikut :

$$
\begin{array}{ll}
0,00-0,199 & =\text { Sangat Rendah } \\
0,20-0,0399 & =\text { Rendah } \\
0,40-0,599 & =\text { Sedang } \\
0,60-0,799 & =\text { Kuat }
\end{array}
$$


Philanthrophy Journal of Psychology

Vol 2 Nomor 1 (2018), 37-54

ISSN 2580-6076 (Print), ISSN 2580-8532 (Online)

$$
0,80-1,000=\text { Sangat Kuat }
$$

Berdasarkan tabel 4.9 uji determinasi diketahui R sebesar 0,983 ini, menunjukkan kekuatan hubungan antara variabel independen (dukungan keluarga dan konsep diri) dengan variabel dependen (keterampilan sosial) masuk kategori sedang.

\section{Diskusi}

Berdasarkan hasil uji hipotesis yang telah dilakukan dapat diketahui bahwa pertanyaan penelitian, apakah ada pengaruh signifikansi antara dukungan keluarga dan konsep diri terhadap ketrampilan sosial anak tunarungu telah terjawab. Dukungan keluarga berpengaruh terhadap keterampilan sosial anak tunarungu. Hal ini selaras dengan pendapat yang diungkapkan Mu'tadin (2006) lingkungan keluarga merupakan suatu bentuk masyarakat kecil yang akan memberikan peran sangat penting dalam mempengaruhi kualitas generasi yang akan datang. Dalam keluarga akan muncul suatu keterampilan sosial yang berkembang dengan nilai-nilai, norma-norma dan keterampilan kerjasama antara anak yang satu dengan anak lainnya, yaitu kemampuan mengadakan toleransi, menghargai orang lain.

Hasil penelitian diatas juga selaras dengan penelitian yang dilakukan oleh Kartika (2008), bahwa keluarga bisa disebut faktor atau kelompok sosial yang memberikan pengaruh yang besar dan paling utama dalam kehidupan manusia. Sehingga seorang individu mendapatkan sebuah harapan baru terhadap solusi permasalahannya. Karena adanya sebuah dukungan sosial maupun moril dari dalam keluarganya.

Berdasarkan beberapa penelitian tentang keterampilan sosial dapat diketahui beberapa hal yang mempengaruhi keterampilan sosial, salah satu faktor yang mempengaruhi keterampilan sosial yang dituliskan oleh Michelson (dalam Ramdhani,1994) adalah dukungan keluarga. Keterampilan sosial bukanlah kemampuan yang dibawa individu sejak lahir tetapi diperoleh melalui proses belajar, baik belajar dari orang tua sebagai figur paling dekat dengan anak maupun belajar dari teman sebaya dan lingkungan masyarakat. Penelitian Brown (2008) menyatakan bahwa memiliki dukungan dari orang lain (misalnya keluarga, rekan, dan anggota masyarakat) dapat menguntungkan bagi orang afrika amerika yang mengalami kesulitan dalam hidup.

Lebih lanjut hasil studi Davis dan Forsythe (Mu'tadin, 2006), terdapat delapan aspek yang mempengaruhi keterampilan sosial dalam kehidupan anak, salah satunya adalah keluarga. Keluarga merupakan tempat pertama dan utama bagi anak dalam 
Philanthrophy Journal of Psychology

Vol 2 Nomor 1 (2018), 37-54

ISSN 2580-6076 (Print), ISSN 2580-8532 (Online)

mendapatkan pendidikan. Kepuasan psikis yang diperoleh anak dalamkeluarga akan sangat menentukan bagaimana ia akan bereaksi terhadap lingkungan.

Libet dan Lewinsohn (dalam Cartledge dan Milburn 1995) mengemukakan “Keterampilan sosial sebagai kemampuan yang kompleks untuk menunjukkan perilaku yang baik dinilai secara positif atau negative oleh lingkungan, dan jika perilaku itu tidak baik akan diberikan punishment oleh lingkungan".

Hasil penelitian ini menunjukkan bahwa secara parsial konsep diri memiliki pengaruh yang signifikan terhadap keterampilan sosial anak tunarungu. Uji hipotesis tersebut menunjukkan hasil yang sama dengan hasil penelitian yang telah dilakukan sebelumnya maupun beberapa teori yang telah ada. Berdasarkan penelitian yang telah dilakukan oleh Jasmine Green (2006) Konsep diri merupakan persepsi mengenai dirinya sendiri yang dibentuk dari pengalaman, perilaku dalam kehidupan sehari-hari dan lingkungan sekitarnya. Pengalaman seseorang dengan lingkungan menjadi penentu konsep diri. Konsep diri bukan sesuatu yang muncul tiba-tiba. Pembentukan konsep diri seseorang sangat dipengaruhi oleh keterampilan sosial.

Berdasarkan hasil penelitian diketahui bahwa secara simultan dukungan keluarga dan konsep diri berpengaruh secara signifikan terhadap keterampilan social anak tunarungu yang menjadi subjek dalam penelitian ini.

Sedangkan melalui uji determinasi $\left(\mathrm{R}^{2}\right)$ diketahui persentase besarnya pengaruh dukungan keluarga dan konsep diri terhadap keterampilan sosial. Berdasarkan uji determinasi diperoleh $\mathrm{R}^{2}$ (R Square) sebesar $96.6 \%$ dukungan keluarga dan strategi konsep diri berpengaruh terhadap keterampilan sosial. hal ini menunjukkan kekuatan hubungan antara variabel independen (dukungan keluarga dan strategi konsep diri) dengan variabel dependen (keterampilan sosial) masuk kategori tinggi.

Berdasarkan hal tersebut diatas dapat dikatakan bahwa pada anak tunarungu yang menjadi subjek penelitian, secara simultan dukungan keluarga dan konsep diri berpengaruh secara signifikan terhadap keterampilan sosial. Sedangkan sisanya (3.4 \%) dipengaruhi oleh variabel lain di luar penelitian ini.

Sebagaimana dikemukakan oleh Comb dan Slaby (1977) Keterampilan sosial adalah suatu kemampuan secara cakap yang tampak dalam tindakan, mampu mencari, memilah dan mengelola informasi, mampu mempelajari hal-hal baru yang dapat memecahkan masalah sehari-hari, mampu memiliki keterampilan berkomunikasi baik 
Philanthrophy Journal of Psychology

Vol 2 Nomor 1 (2018), 37-54

ISSN 2580-6076 (Print), ISSN 2580-8532 (Online)

lisan maupun tulisan, memahami, menghargai, dan mampu bekerjasama dengan orang lain yang majemuk, mampu mentranformasikan kemampuan akademik dan beradaptasi dengan perkembangan masyarakat.

\section{Kesimpulan}

Berdasarkan hasil analisis data penelitian dan pembahasan sebagaimana dibahas pada bab IV, dapat disimpulkan bahwa ada pengaruh antara dukungan keluarga dan konsep diri terhadap keterampilan social anak tunarungu di sekolah inklusif. Siswa tunarungu yang memiliki dukungan keluarga yang baik dan konsep diri yang baik mempunyai keterampilan social yang baik pula. Sementara itu siswa dengan dukungan keluarga yang kurang dan mempunyai konsep diri yang kurang baik akan berpengaruh pada kurangnya keterampilan social yang dimiliki.

\section{Saran}

Penelitian ini diharapkan dapat memberikan gambaran dan masukan kepada orang tua yang memiliki anak tunarungu dalam memberikan dukungan \bagi anak sehingga anak tunarungu mempunyai keterampilan social yang baik. Hasil penelitian ini diperoleh bahwa indikator dukungan keluarga yang paling mempengaruhi keterampilan social anak tunarungu adalah aspek penilaian dimana anak tunarungu membutuhkan penilaian yang positif dari keluarga Adapun hal yang dapat dilakukan orang tua adalah sebagai berikut :

a. Orang tua dapat memberikan dukuangan berupa dukungan penilaian yaitu memberikan kepercayaan pada anak tunarungu terhadap kegiatan-kegiatan yang diikutinya.

b. Kesediaan dan kesabaran orang tua diharapkan untuk dapat membina konsep diri pada anak tunarungu

Penelitian ini diharapkan dapat memberikan manfaat yaitu anak tunarungu dapat membangun komunikasi dengan keluarga, pertemanan dan orang-orang sekitar agar dapat mengembangkan keterampilan social dengan orang-orang sekitar dengan terus memupuk konsep diri yang positif. Hal tersebut sesuai dengan hasil penelitian ini bahwa, dukungan keluarga yang kuatakan mempengaruhi konsep diri yang baik. Dan dengan konsep diri yang baik dapat mempengaruhi keterampilan social yang baik bagi anak tuna rungu. Pada penelitian ini, peneliti mengadaptasi skala penelitian sendiri sehingga masih banyak keterbatasan dalam menterjemahkan indikator ke dalam aitem-aitem yang baik dan tepat. 


\section{Daftar Pustaka}

Agustyawati dan Solicha. (2009). Psikologi pendidikan anak berkebutuhan khusus. Jakarta: Lembaga Penelitian UIN Jakarta

Alfian. (2013). Pendidikan inklusi di Indonesia, edu-bio volume 4

Antia, et al., (2011) .Social Outcomes of Students Who Are Deaf and Hard of Hearing in General Education Classrooms.university of Arizona

Ardha, Ray Yulia. (2017). KeterampilanSosialAnakTunagrahitaRingan Di SekolahDasarInklusi. JurnalJassi_Anakku, Volume 13: Nomor 1.

Arikunto, Suharsimi. (2006). Prosedur penelitian suatu pendekatan praktek. Jakarta: Rineka Cipta.

Baihaqi, M dan Sugiarmin, M. (2006). Memahami dan membantu anak ADHD. Bandung : PT. Refika Aditama.

Bremer, C.D. dan Smith, J. (2004). Teaching social skills. national center on secondary education and transition, 3 (1),

Budiyanto, dkk. (2010). Modul pelatihan pendidikan inklusi. Jakarta: Kementerian Pendidikan Nasional.

Bungin, Burhan. (2005). Metode penelitian kuantitatif. Jakarta: Prenadamedia.

Burns, R.B. (1993)Konsep diri (teori, pengukuran, perkembangan dan prilaku). Jakarta : Arcan.

Cartledge, G. \& Millburn, J. F. (1995). Teaching social skills to children \&youth. innovative aproach, 3rd ed. Massachussets: Allyn \& Bacon.

Combs, ML \&Slaby, DA. (1997). Social skills training with children. New York : Plenum Press

Demaray, M. K., Ruffalo, S. L., Carlson, J., Busse, R. T., Olson, A. E., McManus, S. M., dan Leventhal, A. (1995). Social skills assessment: a comparative evaluation of six publised rating scales. school psychology review, 24 (4)

Desmita. (2012). Psikologi perkembangan peserta didik. Bandung: Rosda Karya.

Devine, Mary Ann. (2004). "Being a "doer" instead of a "viewer"”: the role of inclusive leisure contexts in determining social acceptence for people with disabilities. journal of leisure research. Vol. 36, No. 2. Pp. 137-159.

Farrugia, D. \& Austin, G.F. (1980). A study of social emotional adjusment pattern of hearingimpaired students indifferent educational settings. American \& Annals of he Deef, 125, 535-541. 
Philanthrophy Journal of Psychology

Vol 2 Nomor 1 (2018), 37-54

ISSN 2580-6076 (Print), ISSN 2580-8532 (Online)

Francis \& Satiadarma. (2004). Pengaruh Dukungan Keluarga Terhadap Kesembuhan Ibu Yang Mengidap Kanker Payudara. Jurnal Ilmiah

Psikologi. ARKHE. Th. 9/no.01/2004.

Friedman, M. (2010). Buku ajar keperawatan keluarga : riset, teori, dan praktek. Edisi ke5. Jakarta: EGC

Geldard, K dan Geldard, D. (2012). Konseling anak-anak. Terjemahan oleh Widijanto, G dan Yuwono, L. 2012. Jakarta: Indeks.

Gresham, F. M. dan Elliott, S. N. (1990). Social skills rating system. (Online), (http://overlake.virtual-space.net/SLP/SSRS_locked.pdf), diakses 27 Januari 2018.

Gross, J.J. \& Thompson, R.A. (2006). Emotion regulation: conceptual foundation. in j.j. gross (ed). handbook of emotion regulation. New York: Guilford Press.

Gulo. (2010). Metodologi penelitian. Jakarta : Grasindo

Hallahan, D.P., \& Kauffman, J.M. (2006). Exceptional children: an introduction to special education(10th ed). Boston: Pearson.

Hapsari Puspa Rini. (2014). Peningkatanketerampilan sosial anak tunarungu kelas VI SDLB melalui permainan tradisional pasaran di slb-b wiyata dharma I tempel. Skripsi. Yogyakarta; Fakultas Ilmu Pendidikan Universitas Negeri Yogyakarta.

Hardy, M dan Hayes,S. (1988). Pengantar psikologi. Jakarta : PT Erlangga.

Hurlock, Elizabeth, B (2002). Psikologiperkembangan. 5th edition. Jakarta: Erlangga.

Hurlock, Elizabeth, B. (1997). PsikologiPerkembangan. Jakarta: Erlangga.

Jamilah, Meilita. (2013). Pengaruh Tipe Kepribadian \& Dukungan Sosial Terhadap Subjective Well Being (SWB) Mahasiswa Perantau UIN Syarif Hidayatullah Jakarta. Skripsi. Jakarta; Fakultas Psikologi Universitas Islam Negeri Syarif Hidayatullah.

Kaplan, HI, Saddock, BJ \& Grabb, JA., (2010). Kaplan-Sadock Sinopsis psikiatri ilmu pengetahuan prilaku psikiatri klinis. Tangerang : Bina Rupa Aksara pp.1-8.

Kemendikbud. (2016). Panduan Teknis Pembelajaran dan Penilaian di Sekolah Dasar. Jakarta: Kemendikbud Direktorat Jendral Pendidikan Dasar dan Menengah

Kerlinger, Fred N. (2002). Asas-asas penelitian behavioral. Yogyakarta: Gajah Mada University Press

Lay Kekeh Marthan. (2007). Manajemen pendidikan inklusif. Jakarta: Depdiknas, Dikti, Direktorat Ketenagaan.

Mangunsong, F. (2010). Anak berkebutuhan khusus dan intervensi psikoedukasi materi national series training and workshop for special teacher. Jakarta: Depdiknas 
Mubarak, (2012). Peran Konsep Diri Dan Keterampilan Sosial Dalam Membentuk Karakter Daya Juang Siswa Pesantren. IAIN Antasari Banjarmasin.

Murni Winarsih. (2007). Intervensi Dini Bagi Anak Tunarungu dalam Pemerolehan Bahasa. Departemen Pendidikan dan Kebudayaan. Direktorat Jenderal Pendidikan Tinggi. Direktorat Ketenagaan

Mulyana mutiudin (2018), Hubungan Keluarga Dengan Kemampuan Keterampilan Sosial Anak Berkebutuhan Khusus (Tunarungu) di SLB Yayasan Bahagia Kota Tasikmalaya. Jurnal STIKES Mitra Kencana Tasikmalaya.

Ormrod, J. E. (2009). Psikologi pendidikan jilid 1. Terjemahan oleh Wahyu Indianti. 2009. Jakarta: Erlangga.

Peraturan Menteri Pendidikan Nasional RI No. 70 Tahun 2009 Tentang Pendidikan Inklusif Bagi Peserta Didik Yang Memiliki Kelainan dan Memiliki Potensi atau Bakat Istimewa.

Permanarian, Somad dan Tati Hernawati. (1996). Orthopedagogik tunarungu. Jakarta. Ditjen Dikti.

Rahayu.(2016). Hubungan Antara Konsep Diri Dengan Keterampilan Sosial Anak Taman Kanak-kanak". UPI

Rinipuspahapsari, (2014). Peningkatan Keterampilan Sosial Anak Tunarungu Kelas Vi Sdlb Melalui Permainan Tradisional Pasaran Di Slb-B Wiyata Dharma I Tempel. UNY

Rubin, K. H., Bukowski, W. M., \& Parker, J. G. (2006). Peer interactions, relationship, and groups. dalam w. damon (series eds) \& n. eisenberg (vol. eds), handbook of child psychology (6th edition). New York: John Wiley \& Sons.

Rosse, Umar Djani, Atang Setiawan (2014). Keterampilan Anak Tunagrahita Ringan di Sekolah Inklusif. Jurnal jassi_AnakkuVolume 13 : Nomor 1.

Smith, M.B., Inttenbach, R.F., dan Patton, J.R. (2002). Mental retardation. 6th ed. New Jersey: Merrill Prentice Hall.

Sofy dan Muryantinah. (2014). Hubungan antara dukungan sosial teman sebaya dengan penyesuaian diri siswa tunarungu di sekolah inklusi. Fakultas Psikologi Unoversitas Airlangga.

Soemanto, Wasty. (1998). Psikologi pendidikan. Bandung: Rineka Cipta.

Somantri, Sutjihati. (2005). Psikologi anak luar biasa. Bandung: PT. Refika Aditama.

Spence, S. \& Shepherd, G. (1983). Developments in social skills training. London: Academic Press Inc.

Stainback, W. danStainback, S. (1990). Support networks for inclusive schooling: independent integrated education. Baltimore: Brookes Publishing. 
Philanthrophy Journal of Psychology

Vol 2 Nomor 1 (2018), 37-54

ISSN 2580-6076 (Print), ISSN 2580-8532 (Online)

Staub, D. \& Peck, C.A. (1995).What are the outcomes for nondisabled students? educational leadership. Baltimore: Paul H. Brooks.

Stubbs, S. (2002). Pendidikan inklusif:ketika hanya ada sedikit sumber.(terjemahan). rev ed. oslo : the atlas alliance.

Suharmini, Tin. (2009). Psikologi anak berkebutuhan khusus. Yogyakarta : Kanwa Publisisher.

Tanjung febriana milla, (2014).Interaksi Sosial Anak Tunarungu Di Sd Negeri 4 Bejen Karanganyar. UNY

Tarmansyah. (2007). Inklusi pendidika nuntuk semua. Jakarta: Depdiknas, Dikti, DirektoratKetenagaan.

Wasita,Ahmad. 2013. Seluk beluk tunarungu dan tunawicara serta strategi pembelajarannya. Yogyakarta: Javalitera. 